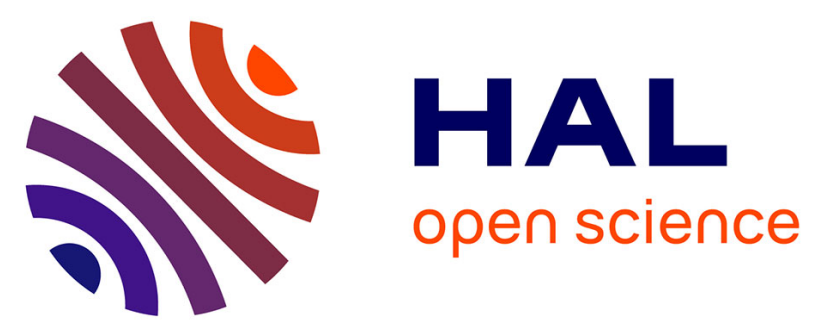

\title{
Transcriptional and post-transcriptional response of drug-metabolizing enzymes to PAHs contamination in red mullet (, Linnaeus, 1758): a field study
}

Camilla Della Torre, Ilaria Corsi, Francesco Nardi, Guido Perra, Maria Paola Tomasino, Silvano Focardi

\section{To cite this version:}

Camilla Della Torre, Ilaria Corsi, Francesco Nardi, Guido Perra, Maria Paola Tomasino, et al.. Transcriptional and post-transcriptional response of drug-metabolizing enzymes to PAHs contamination in red mullet (, Linnaeus, 1758): a field study. Marine Environmental Research, 2010, 70 (1), pp.95. 10.1016/j.marenvres.2010.03.009 . hal-00598195

\section{HAL Id: hal-00598195 https://hal.science/hal-00598195}

Submitted on 5 Jun 2011

HAL is a multi-disciplinary open access archive for the deposit and dissemination of scientific research documents, whether they are published or not. The documents may come from teaching and research institutions in France or abroad, or from public or private research centers.
L'archive ouverte pluridisciplinaire $\mathbf{H A L}$, est destinée au dépôt et à la diffusion de documents scientifiques de niveau recherche, publiés ou non, émanant des établissements d'enseignement et de recherche français ou étrangers, des laboratoires publics ou privés. 


\section{Accepted Manuscript}

Title: Transcriptional and post-transcriptional response of drug-metabolizing enzymes to PAHs contamination in red mullet (Mullus barbatus, Linnaeus, 1758): a field study

Authors: Camilla Della Torre, Ilaria Corsi, Francesco Nardi, Guido Perra, Maria Paola Tomasino, Silvano Focardi

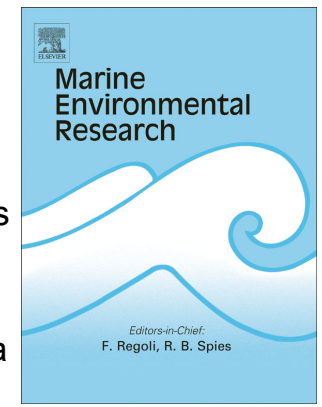

PII:

S0141-1136(10)00049-8

DOI:

10.1016/j.marenvres.2010.03.009

Reference: MERE 3436

To appear in: Marine Environmental Research

Received Date: 22 December 2009

Revised Date: 18 March 2010

Accepted Date: 25 March 2010

Please cite this article as: . Transcriptional and post-transcriptional response of drug-metabolizing enzymes to PAHs contamination in red mullet (Mullus barbatus, Linnaeus, 1758): a field study, (2010), doi: 10.1016/j.marenvres.2010.03.009

This is a PDF file of an unedited manuscript that has been accepted for publication. As a service to our customers we are providing this early version of the manuscript. The manuscript will undergo copyediting, typesetting, and review of the resulting proof before it is published in its final form. Please note that during the production process errors may be discovered which could affect the content, and all legal disclaimers that apply to the journal pertain. 
1 Transcriptional and post-transcriptional response of drug-metabolizing enzymes to PAHs

2 contamination in red mullet (Mullus barbatus, Linnaeus, 1758): a field study

3

4

5

6

7

8

11 Camilla Della Torre ${ }^{1}$, Ilaria Corsi $^{1}$, Francesco Nardi ${ }^{2}$, Guido Perra ${ }^{1}$, Maria Paola Tomasino ${ }^{1}$, 12 Silvano Focardi ${ }^{1}$

13 'Department of Environmental Sciences “G. Sarfatti”, University of Siena, Siena, Italy

$14{ }^{2}$ Department of Evolutionary Biology, University of Siena, Siena, Italy

$17 *$ Corresponding author

18 Camilla Della Torre

19 Department of Environmental Sciences “G. Sarfatti”, University of Siena

20 Via Mattioli, 4

2153100 Siena

22 Italy

23 Tel: +390577 232877

24 Fax: +390577232806

25 E-mail: dellatorre2@unisi.it 
27 Abstract

28 Aim of this study was to evaluate the responsiveness of red mullet (Mullus barbatus) liver

29 detoxification enzymes to PAHs at transcriptional and post-transcriptional levels in the field. Fish

30 were captured in the north-eastern Adriatic Sea, close to an oil refinery. Sixteen PAHs (EPA) were

31 determined in sediments and fish fillets; transcription levels of cypla, cyp3a and abcc2 genes and 32 EROD, BROD, B(a)PMO, BFCOD, GST and UDPGT enzymatic activities were measured. Levels 33 of PAHs in sediments reflect the oil pollution gradient of the area, with weak correspondence in fish 34 fillets. cypla gene transcription and EROD, B(a)PMO and BFCOD activities were significantly 35 induced in the oil refinery site, and a slight up-regulation of cyp $3 a$ and $a b c c 2$ was also observed. 36 GST and UDPGT remained unchanged. The present study provides the first data on detoxification 37 responses at transcriptional levels in the liver of red mullet and confirms phase I enzymes as 38 suitable biomarkers of exposure to PAHs in field studies. 


\section{Introduction}

Petroleum and its derivatives are the major and most widespread type of contaminants in marine coastal areas. Several man-dependant sources are heavy contributors: shipping activities, industrial and urban run-off, oil production and oil refining. Petroleum-related hydrocarbons in the marine environment cause great concern due to their persistence in sediment and their toxicity for marine organisms. Polycyclic aromatic hydrocarbons (PAHs) and their metabolites have the highest toxicity, being mutagenic, cytotoxic and potentially carcinogenic (IARC, 1989). PAHs in the water column and sediments cause a series of harmful effects in vertebrates and invertebrates, including genetic damage, immune and endocrine disfunction, malformations, fibrosis and cancer (Aas et al., 2000). These effects determine a decrease in the survival capacity of resident species and thus a reduction in biodiversity (Shailaja and D'Silva, 2003; Martin-Skilton et al., 2006a; Venturini et al., 2008). Information about PAH bioavailability and the biological responses of organisms, such as mechanisms of cell response, are therefore essential to assess how dangerous these contaminants are in the environment and devise adequate strategies of environmental protection.

The primary biological system for detoxifying/bioactivating PAHs is the cytochrome P450 (CYP450) system (Aas et al., 2000; Jewett et al., 2002; Lee and Anderson, 2005), which consists of several multigenic families of structurally and functionally related heme-proteins (Goksøyr and Förlin, 1992). In fish, two gene subfamilies, namely cypla and cyp3a, encode for key CYP450 enzymes that are known to play a major role in the biotransformation of several compounds including marine pollutants. Response of cypla towards PAHs has been extensively studied and is known to be regulated by the aryl hydrocarbon receptor (AhR) (Stegeman and Hahn, 1994; Hahn, 1998). On the other hand, while cyp3a is known to be involved in the metabolism of several drugs (Hasselberg et al., 2008; Christen et al., 2009), its role and regulation in fish is still matter of debate. Few studies have directly addressed its involvement in the response to environmental contaminants, and field data are lacking altogether. Moreover, species-specific differences in substrate specificity towards different compounds, including $\beta$-naphthoflavone, were recently reported (Smith and Wilson 2010). Enzymatic activities generally associated with CYP3A include benzyloxy-4[trifluoromethyl]-coumarin-O-debenzyloxylase (BFCOD) (Hasselberg et al. 2008; Christen et al. 2009), testosterone hydroxylase (James et al., 2005), aminopyrine $N$-demethylase and erythromycin $N$-demethylase (Vaccaro et al., 2007), with some contradictory results with regards to their modulation in response to xenobiotics (Li et al., 2008).

UDP-glucuronyl transferase (UDPGT) and glutathione-S-transferase (GST) are major enzymes involved in phase II of detoxification. Their response to environmental pollutants, including PAHs, 
seems less pronounced than those of phase I, making them less suitable biomarkers of exposure in fish (van der Oost et al., 2003; Martinez-Gomez et al., 2009).

Among ATP-binding cassette transport proteins, the multi-resistance protein 2 (MRP2), encoded by the $a b c c 2$ gene, excretes conjugated metabolites of phase I and II from cells, and is therefore known as phase III of detoxification (Leslie et al., 2005). The abcc2 sequence has already been identified in some fish species (Sauerborn et al., 2004; Miller et al., 2007; Zaja et al., 2008; Zucchi, 2009) but only few studies investigated its modulation by environmental pollutants. Significant induction of abcc2 gene transcription has been reported in Emerald rock cod (Trematomus bernacchi) exposed to B(a)P (Zucchi, 2009). Similarly Paetzold et al. (2009) reported a significant increase in abcc2 transcription in killifish (Fundulus heteroclitus) from a PAH-contaminated area (Sydney Tar Ponds, Nova Scotia, Canada).

Despite past and recent data on the modulation of detoxification proteins in response to PAHs, significant interest is now summoned by the possibility to link phases I, II and III starting from gene transcription profile (Bard, 2000; Paetzold et al., 2009). Characterization and expression profiling of specific genes, such as cypla, cyp $3 a$ and $a b c c 2$, known to be involved in responses to marine pollutants in selected fish species, can therefore be extremely important in environmental studies to clarify cell detoxification pathways occurring in the natural environment.

Red mullet (Mullus barbatus) have been recommended as a species suitable for use as a bioindicator in Mediterranean marine coastal areas (UNEP RAMOGE, 1999). The species is a territorial benthic fish with well-known ecological and physiological characteristics and pronounced sensitivity to different kinds of pollutants. Red mullet tends to accumulate pollutants to a greater extent than other species (Zorita et al., 2008) and has therefore been used as a bioindicator for pollution monitoring of polychlorinated biphenyls (PCBs), PAHs, alkylphenols and metals (Insausti et al., 2009; Harmelin-Vivien et al., 2009; Ausili et al., 2008; Martin-Skilton et al., 2006b). While pollutant-induced enzymes such as 7-ethoxyresorufin- $O$-deethylase (EROD), benzo(a)pyrene monooxygenase (B(a)PMO), GST and UDPGT have been widely studied in this species (Regoli et al., 2002; Corsi et al., 2002; Porte et al., 2002; Burgeot et al., 1994), no data is currently available, to our knowledge, on the modulation of toxicologically relevant genes at the transcription level. Aim of the present study was to evaluate the responsiveness of red mullet liver detoxification enzymes to PAHs in the field at transcriptional and post-transcriptional levels. The link between phases I, II and III of detoxification in fish in response to exposure to PAHs was also discussed. Specimens of red mullet were captured in three sites with different degrees of PAH contamination: sediment samples, as well fish fillets, were analyzed for PAHs content. Transcription of cypla, 
cyp $3 a$ and $a b c c 2$ genes and activities of EROD, benzyloxyresorufin- $O$-deethylase (BROD), B(a)PMO, BFCOD, GST and UDPGT were assessed in fish liver.

\section{Methods}

\section{$\underline{2.1 \text { Fish and sediment sampling }}$}

115 Specimens of red mullet were captured in November 2007 in the north-eastern Adriatic off a stretch 116 of coast characterized by high human impact, extending from $43.62816^{\circ} \mathrm{N}, 13.44080^{\circ} \mathrm{E}$ to $43.68213^{\circ} \mathrm{N}, 13.31534^{\circ} \mathrm{E}$. Three sites with different degrees of PAHs contamination were considered: one site was directly off an oil refinery (high-impact site HIS) $\left(43.64152^{\circ} \mathrm{N}\right.$, $\left.13.40688^{\circ} \mathrm{E}\right)$. The refinery occupies an area of 70 ha, processes 3.9 million tons of crude oil per year and produces 2 million MWh/y. Storage capacity (about 1,500,000 $\mathrm{m}^{3}$ ) is among the largest in Europe. All the crude oil arrives by sea and refinery products leave by sea (30\%) and land (70\%). The many transport and processing operations lead to frequent accidental spills (the most recent of fuel oil in April 2007). The other two sites were at increasing distances from HIS, one defined as moderate impact (MIS) affected by urban run-off $\left(43.66269^{\circ} \mathrm{N}, 13.34753^{\circ} \mathrm{E}\right)$ and the other as reference $(\mathrm{REF})\left(43.67660^{\circ} \mathrm{N}, 13.33383^{\circ} \mathrm{E}\right)$. The area normally has slow sea currents $(2.5 \mathrm{~m} / \mathrm{sec})$ flowing NW-SE direction, i.e. from the REF to the MIS and HIS sites. The sites were in a 7-Km stretch of sea about $1300 \mathrm{~m}$ from the shore. Trawling was carried out for $900 \mathrm{~m}$ at depths between 20-30 m.

Twenty specimens were collected at each site: HIS specimens were 11.5-13.5 cm TL and weighed 20-45 g, MIS specimens were 11-13 cm TL and weighed 20-40 g, REF specimens were 12-14 cm TL and weighed 26-40 g. All specimens showed recrudescent gonads at the time of sampling, impairing sex determination. Nevertheless previous studies failed to observe any sexual dimorphism for phases I and II in November (Mathieu et al., 1991).

Liver and muscle were immediately excised on board. Liver was flash frozen in liquid nitrogen and stored at $-80^{\circ} \mathrm{C}$ until molecular and biochemical analysis; muscle was stored at $-20^{\circ} \mathrm{C}$ until chemical analysis. At the same time, 25 cores of superficial sediment $(0-10 \mathrm{~cm})$ were obtained in the three

\subsection{PAH analysis}

140 The sixteen most toxic PAHs listed by the EPA were determined in all sediment samples and in

141 four pools of five fish fillets for each site. Five grams of sediment and $5 \mathrm{~g}$ of fish fillet were 142 extracted (Dionex mod. ASE 200 accelerated solvent extractor, Sunnyvale, USA) according to US143 EPA (1996) method 3545A and quantified by high-performance liquid chromatography (HPLC) 
144 (Waters mod. 474 SFD and 996 PDA detectors, Milford, Massachusetts). Quantitative analysis was 145 done against a three-point linear calibration of PAH solution, obtained by dilution of the certified 146 standard mixture TLC 16-PAH mix (Supelco). Satisfactory linearity was obtained, with values of the 147 correlation coefficient $R$ above 0.99. Detection limits, estimated as $3 \sigma$ (IUPAC criterion) for each 148 PAH compound ranged from 0.01 to $0.5 \mathrm{ng} \mathrm{g}^{-1}$. Certified reference materials, procedural blanks and

149 replicate samples were used as quality control procedures, and their reproducibility and recovery 150 were high (>85\%). Precision, evaluated in terms of repeatability of the experimental results $(N=10)$ 151 for the analysis of a real sample and expressed as relative standard deviation, ranged from $4.3 \%$ 152 (DBA) to $18.5 \%$ (NAPH) and was below $10 \%$ in most cases.

\section{$\underline{2.3 \text { Molecular analysis }}$}

155 RNA was isolated from $50 \mathrm{mg}$ of liver samples using the Fatty and Fibrous tissue kit (Biorad, USA)

156

157

158

159

160

161

162

163

164

165

166

167

168

169

170

171

172

173

174

175

176

177 according to the manufacturer's instructions and including a DNAse treatment. RNA concentrations were measured using a Shimadzu spectrophotometer at $260 \mathrm{nM}$. RNA quality was confirmed on $1 \%$ agarose gel that showed discrete $18 \mathrm{~S}$ and $28 \mathrm{~S}$ rRNA bands.

cDNA for RT-PCR was generated with $0.5 \mu \mathrm{g}$ total RNA from all samples in $20 \mu 1$ reaction volume using iScript cDNA Synthesis Kit according to the manufacturer's protocol (Biorad, USA).

Partial sequences for cypla and cyp3a genes were obtained by RT-PCR. cypla sequences of leaping mullet (Liza saliens) (AF072899.1) and gilthead sea bream (Sparus aurata) (AF005719.1) were aligned and primers were designed from highly conserved regions. cyp3a primers were designed using sequences from European sea bass (Dicentrarchus labrax) (DQ268535.1) and rainbow trout (Oncorhyncus mykiss) (AF267126). RT-PCR was performed in an Applied Biosystem Thermal Cycler; the PCR mix contained $1 \mu \mathrm{l}$ cDNA and $1 \mu 1$ of Forward and Reverse primers $10 \mu \mathrm{M}$, in $50 \mu \mathrm{l}$ total volume. The cycling parameters were: 2 min denaturation at $94^{\circ} \mathrm{C}, 35$ cycles at $94^{\circ} \mathrm{C}$ for $30 \mathrm{~s}$, annealing at $55^{\circ} \mathrm{C}$ for $45 \mathrm{~s}$, elongation at $72^{\circ} \mathrm{C}$ for $1 \mathrm{~min}$, and $7 \mathrm{~min}$ final extension at $72^{\circ} \mathrm{C}$. Reaction products were separated by electrophoresis on $1.5 \%$ agarose gel in TBE buffer, stained with ethidium bromide. PCR products were carefully excised from agarose gel and purified with a QIAQUICK Gel Extraction Kit (Qiagen, Germany). PCR products were sequenced by MWG (Germany) and confirmed to be the desired gene fragment by NCBI BlastN.

Real-time PCR was used to evaluate cypla, cyp $3 a$ and $a b c c 2$ gene expression profiles. Primers with an annealing temperature of $55^{\circ} \mathrm{C}$ were designed using IDTDNA www.idtdna.com. $16 \mathrm{~S}$ rRNA was used as housekeeping gene. Each amplification reaction contained $12.5 \mu 1$ SYBR Green mix, $1 \mu 1$ cDNA and $1 \mu \mathrm{l}$ of Forward and Reverse primers $10 \mu \mathrm{M}$ in $25 \mu \mathrm{l}$ total volume. The cycling parameters were: $10 \mathrm{~min}$ denaturation at $95^{\circ} \mathrm{C}, 40$ cycles at $95^{\circ} \mathrm{C}$ for $30 \mathrm{~s}$, annealing at $55^{\circ} \mathrm{C}$ for 
$17845 \mathrm{~s}$, elongation at $72^{\circ} \mathrm{C}$ for $1 \mathrm{~min}$. All primer pairs gave a single peak of dissociation in all 179 reactions, and no amplification occurred in reactions without template. PCR efficiencies for each 180 primer pair were determined from a standard curve using dilutions of pooled cDNA $\left(R^{2}>0.97\right.$ for 181 all primers; efficiencies cypla 99.6\%, cyp3a 98.2 \%, abcc2 105\%, 16S 109\%). Primer sequences 182 used for RT-PCR and qPCR are reported in Table 1. Data were analysed by the $\Delta \Delta \mathrm{Ct}$ method as 183 described by Pfaffl (2001) using Rest 2008 V2.0.7 software, that includes a correction for reaction 184 efficiency. The mathematical model used is based on the correction for exact PCR efficiencies and 185 the mean crossing point deviation between two group(s) (HIS and MIS) and the reference group 186 (REF). Subsequently the expression ratio results of the investigated transcripts are tested for significances by a randomisation test (http://www.gene-quantification.de/rest.html).

\subsection{Biochemical assays}

190 Liver cytosolic and microsomal fractions were obtained as described by Corsi et al. (2003).

191 Microsomal EROD and BROD activities were measured according to the fluorimetric methods of 192 Burke and Mayer (1974). Assay conditions in the reaction mixture (final volume $2.25 \mathrm{ml}$ ) were as 193 follows: $50 \mathrm{mM}$ Tris- $\mathrm{HCl}, 25 \mathrm{mM} \mathrm{MgCl} 2,125 \mu \mathrm{M}$ NADPH and $50 \mu \mathrm{l}$ of liver microsomal fraction.

194 7-ethoxy or benzyloxyresorufin $\left(0.1 \mathrm{mg} \mathrm{ml}^{-1}\right.$ in DMSO) were used as substrate $\left(\mathrm{pH} 7.5,30^{\circ} \mathrm{C}\right)$. The 195 reaction was started by adding $10 \mu \mathrm{NADPH}$, and the increase in fluorescence was recorded for 4 196 minutes at $\lambda_{\mathrm{EX}}=522 \mathrm{~nm} / \lambda_{\mathrm{EM}}=586 \mathrm{~nm}$. Activities were expressed as pmol $\mathrm{min}^{-1} \mathrm{mg} \mathrm{prot}^{-1}$ using a 197 standard curve generated with resorufin.

198 B(a)PMO activity was measured on 12 pools of microsomes (4 per site, 5 individuals each) following the method of Kurelec et al. (1977). Assay conditions in the reaction mixture (final volume $1.01 \mathrm{ml}$ ) were as follows: $110 \mathrm{mM}$ Tris-HCl, $15 \mathrm{mM} \mathrm{MgCl}_{2}, 1.8 \mu \mathrm{M}$ NADPH and $100 \mu \mathrm{l}$ of pooled microsomal fraction $\left(\mathrm{pH} 7.5,30^{\circ} \mathrm{C}\right) . \mathrm{B}(\mathrm{a}) \mathrm{P}(2 \mathrm{mM})$ was used as substrate in a $30 \mathrm{~min}$ reaction stopped with cool acetone. The amount of $3 \mathrm{OH}-\mathrm{B}(\mathrm{a}) \mathrm{P}$ produced was read at $\lambda_{\mathrm{EX}}=396$ $\mathrm{nm} / \lambda_{\mathrm{EM}}=522 \mathrm{~nm}$ with $\mathrm{H}_{2} \mathrm{SO}_{4} 1 \mathrm{M}$ and quinine sulphate $1 \mu \mathrm{g} / \mathrm{ml}$ as standards. B(a)PMO activity was determined in duplicates and compared to a blank treated with acetone prior to incubation; activity was expressed in fluorescence units: $\min ^{-1} \mathrm{mg}_{\operatorname{prot}^{-1}}$.

206 BFCOD activity was measured according to Hasselberg et al. (2008). Reaction mixtures (200 $\mu 1$ total volume) contained: potassium phosphate buffer $0.2 \mathrm{M}, 200 \mu \mathrm{M} \mathrm{BFC}$, bovine serum albumin $(1.6 \mathrm{mg} / \mathrm{ml}), \mathrm{NADPH} 2 \mu \mathrm{M}$ and $10 \mu \mathrm{l}$ of microsomal fraction $\left(\mathrm{pH} 7.4, \mathrm{~T} 30^{\circ} \mathrm{C}\right)$. The reaction was allowed to proceed for 30 minutes, and fluorescence was recorded using a VICTOR3 Multilabel

210 Counter (Wallac Sweden) at $\lambda_{\mathrm{EX}}=410 \mathrm{~nm} / \lambda_{\mathrm{EM}}=538 \mathrm{~nm}$. Activities were expressed as pmol $\mathrm{min}^{-1} \mathrm{mg}$ $211 \operatorname{prot}^{-1}$ using a standard curve generated with 7-hydroxy-4-trifluoromethylcoumarin (HFC). 
212 UDPGT activity was assayed according Collier et al. (2000): $15 \mu \mathrm{l}$ of $20 \mathrm{mM}$ 5'-diphospho213 glucuronic acid was added to a reaction mixture containing $15 \mu 1$ of liver microsomal fraction and $214120 \mu \mathrm{l}$ of $125 \mu \mathrm{M}$ 4-methyl-umbelliferon (4-MU) in $0.1 \mathrm{M}$ Tris $\mathrm{HCl}$ containing $5 \mathrm{mM} \mathrm{MgCl}_{2}$ and $2150.05 \% \mathrm{BSA}(\mathrm{pH} 7.4)$ and incubated for $10 \mathrm{~min}$ at $37^{\circ} \mathrm{C}$. Fluorescence was measured at $\lambda_{\mathrm{EX}}=355$

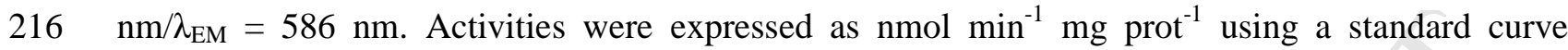
217 generated with 4-MU.

218 GST activity was measured by the spectrophotometric method of Habig et al. (1974) modified for 219 microplate readers. $190 \mu \mathrm{l}$ CDNB $1 \mathrm{mM}\left(\varepsilon=9.6 \mathrm{mM} \mathrm{cm}^{-1}\right)$ dissolved in $0.1 \mathrm{M}$ phosphate buffer $(\mathrm{pH}$ $2207.42, \mathrm{~T} 18^{\circ} \mathrm{C}$ ) and $10 \mu \mathrm{l} \mathrm{GSH} 1.5 \mathrm{mM}$ was added to $20 \mu \mathrm{l}$ diluted cytosolic fractions or 221 homogenizing buffer (reference). Absorbance was measured after 1 minute. Activities were expressed as nmol $\mathrm{min}^{-1} \mathrm{mg} \operatorname{prot}^{-1}$.

223 Total proteins were measured according to Bradford (1976) using bovine serum albumin as 224 standard.

\section{$\underline{2.5 \text { Statistical analysis }}$}

227 Comparisons between sampling sites were evaluated by ANOVA using the Bonferroni post-hoc test except for B(a)PMO activity, for which the Mann-Whitney Wilcoxon rank sum non-parametric test was used. Data was log-transformed to obtain more homogeneous values and correlations between parameters were then determined by Pearson correlation coefficient (r). 0.05 was taken as significance cut-off. Statistical analyses were performed with Statistica 7.1.

\section{Results}

\section{$234 \quad \underline{3.1 \mathrm{PAHs}}$}

235 Concentration of the 16 PAHs measured in sediment from the three sites are reported in Table 2.

236 The highest concentrations were measured at HIS followed by MIS and REF, despite huge 237 variations in all three sites.

238 Similar levels of PAH were observed in fish fillets from specimens collected in HIS and MIS (Tab 239 2). Few inducers of CYP1A were detected in specimens from HIS, and the ranking was pyrene > 240 chrysene > benzo(a)anthracene, and likewise in MIS: pyrene > chrysene > benzo(k)fluoranthene. In 241 REF all PAHs were below the detection limit (Tab 2). 
A 534 bp product was obtained for cypla from liver of red mullet (GenBank accession GQ923895).

247 The sequence was more than 80\% homologous with that of D. labrax (AJ251913.1 E value 1e-37),

248 S. aurata (E value 7e-27), S. quinqueradiata (AB09743.1 E value 5e-35), L. saliens (E value 7e-

249 27), C. labrosus (DQ438983.1 E value 2e-27), P. platessa (X73631.1 E value 1e-29), P. flesus

250 (AJ130767.1 E value 6e-22) and M. curema (AY827103.1 E value 9e-27) cypla.

251 A 345 bp product was also obtained for cyp3a (GenBank accession GQ923894); it showed 70-79\% 252 homology with D. labrax (DQ268535 E value 4 e-63), M. salmoides (3a68 isoform (DQ786406.1 E 253 value 5e-56), F. heteroclitus (3a56 isoform AY143428.1 E value 4 e-51, 3a30 isoform AF105068.2 254 E value 2e-48), O. latipes (AF105018.1 E value 3e-40) and D. rerio (3a65 isoform AY452279.1 E 255 value 7e-35) cyp3a.

\subsubsection{Real-time PCR}

258

259

260

261

262

263

264

265

266

267

268

269

270

271

272

273

274

275

276

277

278

279

Significant up-regulation of cypla and cyp3a transcription was observed in red mullet from HIS with respect to those from REF (REST: $p=0.002$ and 0.021 respectively). cypla was also significantly up-regulated in samples from MIS compared to those from $\operatorname{REF}(p=0.024)$. Relative induction of $a b c c 2$ transcription was observed in mullet from HIS with respect to those from REF, albeit not significant $(p=0.051)$ (Tab 3).

Liver microsomal enzyme activities such as EROD and B(a)PMO again showed significant induction in specimens from HIS and MIS than from REF $(p<0.05)$ (Tab 3). A similar trend was also observed for BFCOD with significantly higher activities in specimens from HIS than REF $(p<0.05)$. No significant differences were observed for BROD activity $(p=0.06)$ or phase II enzymes UDPGT and GST (Tab 4).

Correlations between transcriptional and biochemical parameters are shown in Table 5 as Pearson $r$ correlation coefficient and correlation significance. A marginally significant correlation of EROD, BROD and BFCOD activities with cypla gene transcription was observed, whereas cyp3a did not seem to correlate with BFCOD. No correlation was observed between cypla and the other two genes, whereas a positive significant correlation was observed between cyp $3 a$ and $a b c c 2$. At the biochemical level, strong correlations were observed among EROD, BROD and BFCOD activities. UDPGT and GST did not show any correlation with other markers.

\section{Discussion}

Aim of the present study was to investigate the response to PAH contamination in liver of red mullets from an oil-affected site by investigating modulation of phase I and III at transcriptional level and phase I and II at post-transcriptional level. 
PAH levels in sediments confirmed field exposure to contaminants of industrial origin, with higher levels in HIS and MIS than in REF. HIS resulted moderately contaminated while MIS and REF were slightly contaminated according to the worldwide sediment classification of Notar et al. (2001). Observed PAHs proved to be of pyrolitic and petrogenic origin and known inducers of CYP1A were detected, such as Benzo(a)pyrene and Dibenzo(a,h)anthracene (Lee and Anderson, 2005).

Regarding PAH concentrations in fillets, specimens from HIS had higher levels of contaminants than red mullet from other Adriatic coastal areas (Corsi et al., 2002; Perugini et al., 2007), in line with the hypothesis that HIS is characterized by high levels of PAHs contaminants, that in turn are accumulated in fish tissues despite rapid biotransformation of these xenobiotics. On the other hand, high molecular weight PAHs were not found in fillets from any of the three sites, despite their presence in sediments, as a likely consequence of quick metabolization. Unfortunately, it was not possible to assess PAHs biotransformation more systematically by investigating bile metabolites, as the gall bladder was so small enabling the dissection from fish. Such measurement was nevertheless retained as PAH content in mullet fillets is an important ecological and trophic indicator of transfer to terminal consumers, including humans. The study of liver detoxifying responses at different levels (transcriptional and post-transcriptional) in species from PAH-contaminated areas is therefore important to understand the detoxifying capacity of the species and metabolism of PAHs under natural conditions.

The significantly higher cypla transcription levels observed in liver of red mullet specimens from HIS than in those from REF seem to confirm field exposure to PAHs known to be cypla inducers. Similarly, EROD activity was significantly higher in liver of mullet from HIS than from REF, confirming this induction. The extent of EROD induction was higher than the response at the cypla gene level, observation that might nevertheless be biased by the relatively high transcript level in mullet from REF. In line with this, EROD activity in fish from REF was high compared to activities in fish from other moderately polluted areas though still well below those observed in fish from harbour areas (Barcelona) (Porte et al., 2002; Corsi et al., 2002). This discrepancy in the extent of induction has been previously reported for different species and type of contaminants. Quiròs and collaborators (2007) underlined that the extent of cypla induction towards classical inducers ( $\beta-\mathrm{NF})$ seemed species-specific and relatively high levels of cypla expression were also found in field studies. Referring to field studies in oil-polluted marine areas, a low correlation between cypla gene transcription and EROD activity was also reported by Kammann and collaborators (2008) in dab

312 (Limanda limanda) collected in the North and Baltic sea and in European flounder (P. flesus) 313 exposed to different contaminants (including PAHs) (George et al., 2004). 
314 Several reasons can be hypothesized for the observed discrepancy in the extent of induction of 315 cypla gene transcription and EROD activity, such as different turnover rates and induction timing 316 between transcription and enzyme activity (Tukey and Johnson, 1990), different sensitivity towards 317 classical inducers at transcript level, mRNA processing, transport and stability, protein stability and 318 heme incorporation (Okey, 1990).

319 Regarding the other phase I activity, B(a)PMO response proved to be in line with that of EROD and 320 the level of PAH contamination of the sites. Compared to previous studies, measured activities were 321 similar to those observed in harbours and industrial settings and much higher than those measured 322 in relatively uncontaminated sites (Corsi et al., 2002).

323 cyp3a gene transcription levels were moderately up-regulated in specimens from HIS than REF, 324 whereas BFCOD activities showed significant positive correlations with dealkylating activities (EROD and BROD) and cypla transcription. No correlation was otherwise observed between cyp3a transcription and BFCOD activities. BFCOD is widely used as a measure of CYP3A activity, although the substrate BFC is not strictly specific for CYP3A and is metabolized also by other CYPs (Cheng et al. 2009; Renwick et al. 2000). Furthermore, fish show multiple cyp3a isoforms with different expression patterns and distributions. Taken together our results suggest that quantification of cyp3a transcription and BFCOD activity in liver of red mullet might not be measurements of the same biological response. Nevertheless the good positive correlation between BFCOD, cypla gene transcription and dealkylating activities underlines the need for further investigation of genes encoding this activity and indicates BFCOD as a possible general marker of CYP induction by PAHs, in this species. A CYP3A induction model using primary mullet hepatocytes would be needed to establish whether CYP3A catalytic assays are reliable markers of PAH contamination, as suggested in other species (Christen et al., 2009), and to investigate the relationship between cyp3a and BFCOD.

338 Concerning phase II, our results seem in line with previous field studies that failed to observe any 339 alteration in GST and UDPGT activities in fish resident in PAH-contaminated sites (for a review 340 see van der Oost et al., 2003; Martinez-Gomez et al., 2009) although some evidence of inhibition of 341 GST activity has been reported in fish from PAH-contaminated sites (Bagnasco et al., 1991; 342 Tuvikene et al., 1999). The different trends observed for GST and UDPGT activities with respect to 343 other parameters is somehow unexpected as GST and UDPGT are actively involved in cell 344 detoxification and glutathione conjugates in particular are the preferential substrates of MRP2 345 (Leslie et al., 2005). A possible explanation could be found in the fact that the two enzymes may be 346 affected by additional factors beside the presence of PAHs. Furthermore, as both GST and UDPGT 347 have several isoforms with different functions and ligand preferences, the study of catalytic 
activities alone might be a substantial limit to our complete understanding of the responses of these enzymes.

In phase III, $a b c c 2$ response appeared to be modulated to a lesser extent by PAH contamination than cypla and cyp3a. A possible explanation could be that other ABC transporters besides MRP2 are involved in PAHs metabolites transport in red mullet liver as observed also in human Caco-2 cells (Lampen et al., 2004).

Regarding our aim to investigate detoxification pathways in relation to phase I, II and III, markers of at least two phases (I, III) followed a similar trend of up-regulation in accordance with levels of PAHs contamination, while markers of phase II appeared relatively stable. On an individual basis significant correlations have been observed only between phase I markers, with the exception of cyp $3 a$ that in turn correlates with $a b c c 2$ (phase III). This is in line with observations in fish and mammals where cyp3a and MRPs are often co-expressed (Bresolin et al., 2005; Xu et al., 2005).

Taken together these results suggest the occurrence of at least two groups of markers that are coordinated but differently regulated in response to PAHs, possibly following distinct induction pathways of response to environmental contamination.

To our knowledge, these are the first data on cyp $3 a$ and $a b c c 2$ transcription in liver of a marine fish species in the field. Together with CYP1A, both seem suitable candidates as markers of exposure, although chemical inducers and regulation pathways remain to be studied in more details. Furthermore, as CYP1A, CYP3A and MRP2 are involved in the metabolism and transport of important endogenous compounds, including hormones (Hasselberg et al., 2008; Zaja et al., 2008), this contaminant-induced modulation may impair important physiological functions and be deleterious for the organism.

\section{Conclusions}

The present study provides the first data on responses of toxicologically important genes in a key bioindicator species, the red mullet. CYP1A was confirmed as a sensitive marker of exposure to PAHs in the field at transcription and post-transcription levels, though EROD proved to be a more sensitive indicator of exposure under natural conditions. The low responsiveness of cyp $3 a$ and $a b c c 2$ to PAH contamination suggests that, although these genes could be potential markers of exposure, further validation is needed. Our results indicate that BFCOD must be used with care as a specific activity of cyp3a and might be better regarded as a general marker of CYP induction. Transcription data on phase I and III in liver of red mullet is a first step towards understanding the cell detoxification response at gene level for future pollution monitoring in the Mediterranean. As biotransformation of PAHs is considered a prerequisite for carcinogenesis (van der Oost et al., 
382

383

384

385

386

387

388

389

390

391

392

393

394

395

396

397

398

399

400

401

402

403

404

405

406

407

408

409

410

411

412

413

414

1994), the cell response at mRNA level can provide an early warning of detrimental effects occurring later at higher biological levels. Nevertheless, the low sensitivities observed for some of these responses underline the need for extensive lab and field validation of mRNA-based biomarkers in this species.

\section{Acknowledgments}

The authors are grateful to Giacomo Guerrini, Cristiana Sensini, Anna Trisciani, Valerio Volpi and Sara Zucchi for technical assistance during the sampling campaign. Many thanks to Prof. Francesco Frati for his valuable suggestions during CYP1A and CYP3A sequencing.

\section{References}

Aas, E., Baussant, T. Balk, L., Liewenborg, B., Andersen, O.K., 2000. PAH metabolites in bile, cytochrome P4501A and DNA adducts as environmental risk parameters for chronic oil exposure: a laboratory experiment with Atlantic cod. Aquatic Toxicology 51, 241-258.

Ausili, A., Gabellini, M., Cammarata, G., Fattorini, D., Benedetti, M., Pisanelli, B., Gorbi, S., Regoli, F., 2008. Ecotoxicological and human health risk in a petrochemical district of southern Italy. Marine Environmental Research 66, 215-217.

Bagnasco, M., Camoirano, A., De Flora, S., Melodia, F., Arillo, A., 1991. Enhanced liver metabolism of mutagens and carcinogens in fish living in polluted seawater. Mutation Research 262, 129-137.

Bard, S.M., 2000. Multixenobiotic resistance as a cellular defense mechanism in aquatic organisms. Aquatic Toxicology 48, 357-389.

Bradford, M., 1976. A rapid and sensitive method for the quantitation of microgram quantities of protein utilizing the principle of protein-dye binding. Analytical Biochemistry 72, 248-254.

Bresolin, T., de Freitas Rebelo, M., Bainy, A.C.D., 2005. Expression of PXR, CYP3A and MDR1 genes in liver of zebrafish. Comparative Biochemistry and Physiology C 140, 403-407.

Burgeot, T., Bocquene, G., Pingray, G., Godefroy, D., Legrand, J., Dimeet, J., Marco, F., Vincent, F., Henocque, Y., Jennaret, H.O., Galgani, F., 1994. Monitoring biological effects of contamination in marine fish along French coasts by measurement of ethoxiresorufin-O-deethylase activity. Ecotoxicology and Environmental Safety 29, 131-147.

Burke, M.D., Mayer, R.T., 1974. Ethoxyresorufin: direct fluorimetric assay of microsomal Odealkylation which is preferentially induced by 3 methylcholantrene. Drug Metabolism and Disposition 2, 583-588. 
415 Cheng, Q., Christal, D.S., Guengerinch, F.P., 2009. High-throughput fluorescence assay of 416 cytochrome P450 3A4. Nature Protocols 4(9), 1258-1259.

417 Christen, V., Oggier, D.M., Fent K., 2009. A Microtiter-Plate Based Cytochrome P4503A Activity 418 Assay in Fish Cell Lines. Environmental Toxicology and Chemistry 26:1.

419 Collier, A.C., Tingle, M.D., Keelan, J.A., Paxton, J.W., Mitchell, M.D., 2000. A highly sensitive 420 fluorescent microplate method for the determination of UDP-glucoronosyl transferase activity in 421 tissues and placental cell lines. Drug Metabolism and Disposition 28, 1184-1186.

422 Corsi, I., Mariottini, M, Menchi, V., Sensini, C., Balocchi, C., Focardi, S., 2002. Monitoring a 423 marine coastal area: use of Mytilus galloprovincialis and Mullus barbatus as bioindicators. Marine 424 Ecology 23, 138-153.

425 Corsi, I., Mariottini, M., Sensini, C., Lancini, L., Focardi, S., 2003. Cytochrome P450, 426 acetylcholinesterase and gonadal histology for evaluating contaminant exposure levels in fishes 427 from a highly eutrophic brackish ecosystem: Orbetello Lagoon, Italy. Marine Pollution Bulletin 46, $428 \quad 203-212$.

429 George, S., Gubbins, M., MacIntosh, A., Reynolds, W., Sabine, V., Scott, A., Thain, J., 2004. A 430 comparison of pollutant biomarker responses with transcriptional responses in European flounders 431 (Platicthys flesus) subjected to estuarine pollution. Marine Environmental Research 58, 571-575.

432 Goksøyr, A., Förlin, L., 1992. The cytochrome P-450 system in fish, aquatic toxicology and 433 environmental monitoring. Aquatic Toxicology 22, 287-312.

434 Habig, W.H., Pabst, M.J., Jakoby, W.B., 1974. Glutathione S-transferases. The first enzymatic step 435 in mercapturic acid formation. Journal of Biological Chemistry 249, 7130-7139.

436 Hahn, M.E., 1998. The aryl hydrocarbon receptor: a comparative perspective. Comparative 437 Biochemistry and Physiology C 121, 23-53.

438 Harmelin-Vivien, M., Cossa, D., Crochet, S., Bănaru, D., Letourneur, Y., Mellon-Duval, C., 2009.

439 Difference of mercury bioaccumulation in red mullets from the north-western Mediterranean and 440 Black seas. Marie Pollution Bulletin 58, 679-685.

441 Hasselberg, L., Westerberg, S., Wassmur, B., Celander, M.C., 2008. Ketoconazole, an antifungal 442 imidazole, increases the sensitivity of rainbow trout to $17 \alpha$-ethynylestradiol exposure. Aquatic 443 Toxicology 86, 256-264.

444 IARC, 1989. Diesel and Gasoline Engine Exhausts and some Nitroarenes. IARC Monographs on 445 the Evaluation of Carcinogenic Risk of Chemicals to Humans, vol. 46, Lyon, International Agency 446 for Research of Cancer, France. 
447

448

449

450

451

452

453

454

455

456

457

458

459

460

461

462

463

464

465

466

467

468

469

470

471

472

473

474

475

476

477

478

479

Insausti, D., Carrasson, M., Mainou, F., Cartes, J.E., Solè, M., 2009. Biliary fluorescent aromatic compounds (FACs) measured by fixed wavelength fluorescence (FF) in several marine fish species from the NW Mediterranean. Marine Pollution Bulletin 58, 1635-1642.

James, M.O., Zhen, L., Rowland-Faux, L., Celander, M., 2005. Properties and regional expression of a CYP3A-like protein in channel catfish intestine. Aquatic Toxicology 72, 361-371.

Jewett, S.C., Dean, T.A., Woodin, B.R., Hoberg, M.H., Stegeman, J.J., 2002. Exposure to hydrocarbons 10 years after the Exxon Valdez oil spill: evidence from cytochrome P4501A expression and biliary FACs in near shore demersal fishes. Marine Environmental Research 54, $21-$ 48.

Kamman, U., Lang, T., Berkau, A-J., Klempt, M., 2008. Biological effect monitoring in dab (Limanda limanda) using gene transcript of CYP1A1 or EROD-a comparison. Environmental Sciences and Pollution Research 15, 600-605.

Kurelec, B., Britvic, S., Rijavec, M., Muller, W.E.G., Zahn, R.K., 1977. Benzo(a)pyrene monooxigenase induction in marine fish. Molecular response to oil pollution. Marine Biology 44,211-216.

Lampen, A., Ebert, B., Stumkat, L., Jacob, J., Seidel, A., 2004. Induction of gene expression of xenobiotic metabolism enzymes and $\mathrm{ABC}$-transport proteins by PAH and reconstituted PAH mixture in human Caco-2 cells. Biochimica and Biophysica Acta 1681, 38-46.

Lee, R.F., Anderson J.W., 2005. Significance of cytochrome P450 system responses and levels of bile fluorescent aromatic compounds in marine wildlife following oil spills. Marine Pollution Bulletin 50, 705-723.

Leslie, E.M., Deeley, R.G., Cole, S.P., 2005. Multidrug resistance proteins: role of P-glycoprotein, MRP1, MRP2, and BCRP (ABCG2) in tissue defense. Toxicology and Applied Pharmacology 204, 216-237.

Li, D., Yang, X-L., Zhang S-J., lin, M., Yu, W-J., Hu, K., 2008. effects of mammalian CYP3A inducers on CYP3A-related enzyme activities in grass carp (Ctenopharyngodon idellus): possible implications for the establishment of a fish CYP3A induction model. Comparative Biochemistry and Physiology C 147, 17-29.

Martin-Skilton, R., Thibaut, R., Porte, C., 2006a. Endocrine alteration in juvenile cod and turbot exposed to dispersed crude oil and alkylphenols, Aquatic Toxicology 78S, S57-S64.

Martin-Skilton, R., Lavado, R., Thibaut, R., Minier, C., Porte, C., 2006b. Evidence of endocrine alteration in the red mullet, Mullus barbatus from the NW Mediterranean. Environmental Pollution $141,60-68$. 
480

481

482

483

484

485

486

487

488

489

490

491

492

493

494

495

496

497

498

499

500

501

502

503

504

505

506

507

508

509

510

511

512

Martínez-Gómez, C., Fernández, B., Valdés, J., Campillo, J.A., Benedicto, J., Sánchez, F., Vethaak, A.D. 2009. Evaluation of three-year monitoring with biomarkers in fish following the Prestige oil spill (N Spain). Chemosphere 74, 613-620.

Mathieu, A., Lemaire, P., Carriere, S., Drai, P., Giudicelli, J., Lafaurie, M., 1991. Seasonal and sexlinked variations in hepatic and extrahepatic biotransformation activities in Striped mullet (Mullus barbatus). Ecotoxicology and Environmental Safety 22, 45-57.

Miller, D.S., Shaw, J.R., Stanton, C.R., Barnaby, R., Karlson, K.H., Hamilton, J.W., Stanton, B.A., 2007. MRP2 and Acquired Tolerance to Inorganic Arsenic in the Kidney of Killifish (Fundulus heteroclitus). Toxicological Sciences 97, 103-110.

Notar, M., Leskovšek, H., Faganeli, J., 2001. Composition, Distribution and Sources of Polycyclic Aromatic Hydrocarbons in Sediments of the Gulf of Trieste, Northern Adriatic Sea. Marine Pollution Bulletin 42, 36-44.

Okey A.B., 1990. Enzyme induction in the cytochrome P-450 system. Pharmacology \& Therapeutics 45, 241-298.

Paetzold, C. S., Ross, N.W., Richards, R.C., Jones, M., Hellou, J., Bard, S.M. 2009. Up-regulation of hepatic ABCC2, ABCG2, CYP1A1 and GST in multixenobiotic-resistant killifish (Fundulus heteroclitus) from the Sydney Tar Ponds, Nova Scotia, Canada. Marine Environmental Research $68,37-47$.

Perugini, M., Visciano, P., Giammarino, A., Manera, M., Di Nardo, W., Amorena, M., Polycyclic aromatic hydrocarbons in marine organisms fro the Adriatic Sea, Italy. Chemosphere 66, 19041910.

Pfaffl, M., 2001. A new mathematical model for relative quantification in real-time RT-PCR. Nucleic Acids Research 29, 2002-2007.

Porte, C., Escartin, E., Gracia de la Parra, L.M., Biosca, X., Albaiges, J., 2002. Assessment of coastal pollution by combined determination of chemical and biochemical markers in Mullus Barbatus. Marine Ecology Progress Series 235, 205-216.

Quiròs, L., Piña, B., Sole’, M., Blasco, J., Ángel Lòpez, M., Riva, M.C., Barceló, D., Raldùa, D., 2007. Environmental monitoring by gene expression biomarkers in Barbus graellsii: Laboratory and field studies. Chemosphere 67, 1144-1154.

Regoli, F., Pellegrini, D., Winston, G.W., Gorbi, S., Giuliani, S., Virno-Lamberti, C., Bompadre, S., 2002. Application of biomarkers for assessing the biological impact of dredged materials in the Mediterranean: the relationship between antioxidant responses and susceptibility to oxidative stress in the red mullet (Mullus barbatus). Marine Pollution Bulletin 44, 912-922. 
513 Renwick, A.B., Surry, D., Price, R.J., Lake, B.G., Evans, D.C., 2000. Metabolism of 7-benzyloxy-

514 4-trifluoromethyl-coumarin by human hepatic cytochrome P450 isoforms. Xenobiotica 30, 955515969.

516 Sauerborn, R., Stupin Polancec, D., Zaja, R., Smital, T., 2004. Identification of the multidrug resistance-associated protein (mrp) related gene in red mullet (Mullus barbatus) Marine 518 Environmental Research 58, 199-204.

519 Shailaja, M.S., D'Silva C., 2003. Evaluation of impact of PAH on a tropical fish, Oreochromis 520 mossambicus using multiple biomarkers. Chemosphere 53, 835-841.

521 Smith, E.M., Wilson, J.Y., 2010. Assessment of cytochrome P450 fluorimetric substrates with 522 rainbow trout and killifish exposed to dexamethasone, pregnenolone-16 $\alpha$-carbonitrile, rifampicin, 523 and $\beta$-naphtoflavone. Aquat. Toxicol. doi:10.1016/j.aquatox.2010.01.005.

524 Stegeman, J.J., Hahn, M.E., 1994. Biochemistry and molecular biology of monooxygenases: current 525 perspectives on forms, functions and regulation of cytochrome P450 in aquatic species. In: Malins,

527 Perspectives. Lewis Publisher Inc., Boca Raton, FL, pp. 87-204.

528 Tukey, R.H., Johnson, E.F., 1990. Molecular aspects of drug metabolizing enzymes. In Pratt, W., 529 Taylor, P., (Eds), Principles of drug action. Churcill Livingstone, New York, pp 423-468.

530 Tuvikene, A., Huuskonen, S., Koponen, K., Ritola, O., Mauer, U., Lindström-Seppa, P., 1999. Oil 531 shale processing as a source of aquatic pollution: monitoring of the biologic effects in caged and 532 feral freshwater fish. Environmental Health Perspectives 107, 745-752.

533 UNEP/RAMOGE, 1999. Manual on the biomarkers recommended for the MED POL biomonitoring 534 programme. UNEP, Athens.

535 US-EPA, 1996. US EPA method 3545B. Pressurized Fluid Extraction (PFE), Office of Water, 536 Washington, D.C.

537 Vaccaro, E., Salvetti, A., Del Carratore, R., Nencioni, S., Longo, V., Gervasi, P.G., 2007. Cloning, 538 tissue expression, and inducibility of CYP3A79 from Sea Bass (Dicentrarchus labrax). Journal of 539 Biochemical and Molecular Toxicology 21, 32-40.

540 van der Oost, R., van Schooten, F.J., Ariese, F., Heida, H., Vermeulen, N.P.E., 1994. 541 Bioaccumulation, Biotransformation and DNA binding of PAHs in feral eel (Anguilla anguilla) 542 exposed to polluted sediments: a field survey. Environmental Toxicology and Chemistry 13, 859543870.

544 van der Oost, R., Beyer, J., Vermeulen, N.P.E., 2003. Fish bioaccumulation and biomarkers in 545 environmental risk assessment: a review. Environental Toxicology and Pharmacology 13, 57-149. 
546 Venturini, N., Muniz, P., Bícego, M.C., Martins, C.C., Tommasi, L.Z., 2008. Petroleum

547 contamination impact on macrobenthic communities under the influence of an oil refinery:

548 Integrating chemical and biological multivariate data. Estuarine, Coastal and Shelf Science 78, 457-

549467.

550 Xu, C.C., Yong-Tao, L., Kong, A.N.T., 2005. Induction of Phase I, II, III Drug

551 Meatabolism/Transport by Xenobiotics. Archives of Pharmacology Research 28, 249-268.

552 Zaja, R., Munić, V., Sauerborn Klobučar, R., Ambriović-Ristov, A., Smital, T., 2008. Cloning and 553 molecular characterization of apical efflux transporters (ABCB1, ABCB11 and ABCC2) in rainbow 554 trout (Oncorhynchus mykiss) hepatocytes. Aquatic Toxicology 90, 322-332.

555 Zorita, I., Ortiz-Zarragoitia, M., Apraiz, I., Cancio, I., Orbea, A., Soto, M., Marigòmez, I., 556 Cajaraville, M.P., 2008. Assessment of biological effects of environmental pollution along the NW 557 Mediterranean Sea using red mullets as sentinel organisms. Environmental Pollution 153, 157-168.

558 Zucchi, S. 2009. ABC transporters in the Antarctic Emerald rock cod Trematomus bernacchii. 559 Doctoral thesis $142 \mathrm{pp}$. 
Table 1: Primers sequences, temperature and efficiency

\begin{tabular}{|c|c|c|c|c|c|c|}
\hline Gene & Sense 5'-3' & Antisense $5^{\prime}-3^{\prime}$ & $\begin{array}{c}\text { Temperature } \\
\left({ }^{\circ} \mathrm{C}\right)\end{array}$ & $\begin{array}{c}\text { Size } \\
\text { bp }\end{array}$ & $\begin{array}{l}\text { Accession } \\
\text { number }\end{array}$ & $\begin{array}{c}\text { Efficiency } \\
\%\end{array}$ \\
\hline \multicolumn{7}{|c|}{ RT-PCR } \\
\hline cypla & TTGTCAACGACCTGTTTGGA & TATGTCCAGGAATGGTGTGG & 55 & 534 & & \\
\hline cyp3a & CTG TCC TTC ATC CCC TCC ACG & GGC CTG GTA CTC CAC AGG TTC & 55 & 345 & & \\
\hline \multicolumn{7}{|c|}{ qPCR } \\
\hline cyp1a & CAACAAACTGGAAGGGGAGA & TGGATAATGATTGCCAAGAAGA & 55 & 111 & GQ923895 & 99.6 \\
\hline cyp3a & ATTAAATCCAACCGCGAGGGCA & AGGCCTTTACTCTGGGTTCCTT & 55 & 113 & GQ923894 & 98.2 \\
\hline$a b c c 2$ & CTGGAAGTGCTGCCTGGAG & TGCAGGTAGACATCAGCGTCA & 55 & 125 & AY275434 & 105 \\
\hline 16S rRNA & GGCCGGATCTTGTAGGTCAG & GCCCAAATGTTTTTGGTTGG & 55 & 127 & AF227679 & 109 \\
\hline
\end{tabular}


Table 2: Concentrations of 16 most toxic PAHs indicated by EPA (ng/g) in sediments and fish fillets from the three sites. Results are mean of 25 distinct sediment samples collected at each site and 4 pools of fish fillets from each site. Range of $\Sigma 16$ PAHs is reported for sediments below detection limit (-).

\begin{tabular}{|c|c|c|c|c|c|c|}
\hline & \multicolumn{2}{|c|}{ HIS } & \multicolumn{2}{c|}{ MIS } & \multicolumn{2}{c|}{ Ref } \\
\hline & sediment & fillet & sediment & fillet & sediment & fillet \\
\hline Naphtalene & 47.64 & 9.49 & 1.73 & 8.70 & 5.13 & - \\
\hline Acenaphtylene & 54.60 & 14.06 & - & - & 10.38 & - \\
\hline Acenaphtene & 99.23 & 40.45 & - & 42.40 & 2.26 & - \\
\hline Fluorene & 19.21 & 3.13 & 0.57 & 3.19 & 4.96 & - \\
\hline Phenanthrene & 3.92 & 1.17 & 2.00 & 2.89 & 2.23 & - \\
\hline Anthracene & 2.48 & 3.31 & 0.19 & 2.06 & 2.19 & - \\
\hline Fluoranthene & 9.91 & 15.73 & 2.80 & 52.51 & - & - \\
\hline Pyrene & 10.05 & 6.47 & 1.87 & 21.57 & 1.27 & - \\
\hline Benzo( g.h.i)pherylene & 12.56 & 7.16 & 2.32 & 8.97 & 1.59 & - \\
\hline Benzo(a)anthracene & 10.27 & 1.58 & 1.58 & - & 0.28 & - \\
\hline Chrysene & 9.84 & 1.59 & 1.30 & 4.12 & 1.18 & - \\
\hline Benzo(b)fluoranthene & 7.35 & - & 2.14 & - & 0.48 & - \\
\hline Benzo(k)fluoranthene & 4.89 & - & 1.05 & 0.63 & 0.52 & - \\
\hline Benzo(a)pyrene & 10.47 & - & 1.48 & - & 0.06 & - \\
\hline Dibenzo(a,h)anthracene & 79.07 & - & 0.10 & - & 3.54 & - \\
\hline Indenopyrene & 7.39 & - & 2.16 & - & 0.44 & - \\
\hline Range E16 PAHs & $0.41 / 564.5$ & $-/ 124.28$ & $-/ 37.09$ & $-/ 78.77$ & $-/ 32.72$ & $-/-$ \\
\hline
\end{tabular}


Table 3 . Normalised relative transcription ratio of cypla, cyp3a and abcc2 in red mullet from HIS and MIS obtained through REST Relative expression software 2008 V2.0.7. Data are expressed as relative fold induction with respect to the Reference site. $N=10$ each site

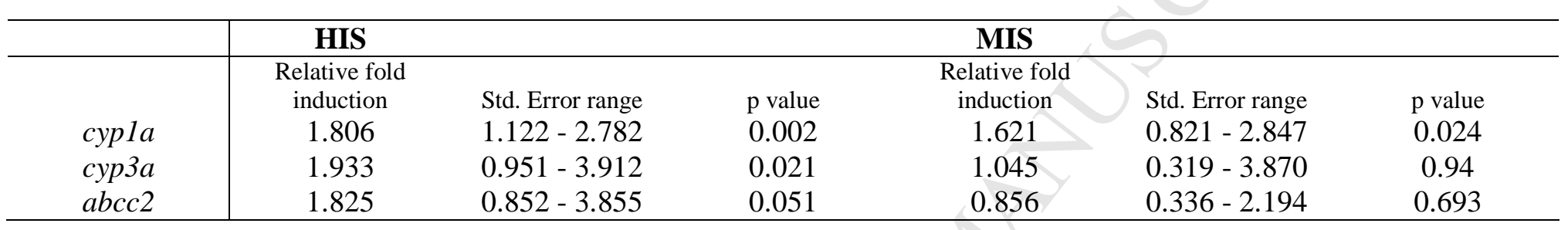


Table 4. Hepatic microsomal and citosolic enzyme activities of red mullet samples from the three sites. $N=20$ each site

\begin{tabular}{|c|c|c|c|}
\hline & HIS & MIS & Ref \\
\hline EROD $^{\mathrm{a}}$ & $329.0 \pm 38.86 *$ & $241.8 \pm 29.26 *$ & $134.0 \pm 14.55$ \\
\hline $\mathrm{BROD}^{\mathrm{a}}$ & $8.846 \pm 0.90$ & $7.368 \pm 0.59$ & $5.959 \pm 0.43$ \\
\hline $\mathrm{B}(\mathrm{a}) \mathrm{PMO}^{\mathrm{b}}$ & $251.4 \pm 38.19 *$ & $140.5 \pm 7.89 *$ & $114.5 \pm 7.48$ \\
\hline $\mathrm{BFCOD}^{b}$ & $32.79 \pm 6.56 *$ & $16.89 \pm 3.38$ & $9.46 \pm 3.31$ \\
\hline $\mathrm{GST}^{\mathrm{c}}$ & $76.80 \pm 4.20$ & $89.44 \pm 4.36$ & $83.64 \pm 4.62$ \\
\hline $\mathrm{UDPGT}^{\mathrm{c}}$ & $2.534 \pm 0.51$ & $3.888 \pm 0.26$ & $2.913 \pm 0.21$ \\
\hline
\end{tabular}

* significant difference $(\mathrm{p}<0.05)$ with respect to the Reference site

${ }^{a} \mathrm{pmol} \min ^{-1} \mathrm{mg} \mathrm{prot}^{-1}$

${ }^{\mathrm{b}} \mathrm{UF} \min ^{-1} \mathrm{mg} \operatorname{prot}^{-1}$

${ }^{\mathrm{c}} \mathrm{nmol} \min ^{-1} \mathrm{mg} \operatorname{prot}^{-1}$ 
Table 5 .Correlations among cypla, cyp3a and abcc2 gene transcription levels and BFCOD, EROD, BROD, GST and UDPGT enzymatic activities

\begin{tabular}{|c|c|c|c|c|c|c|c|c|c|}
\hline & & cypla & cyp3a & $a b c c 2$ & BFCOD & EROD & BROD & GST & UDPGT \\
\hline \multirow[t]{2}{*}{ cypla } & $r$ coeff & 1.00 & 0.2311 & 0.1198 & 0.4383 & 0.4348 & 0.4827 & -0.1211 & 0.1270 \\
\hline & $p$ & & 0.246 & 0.544 & 0.047 & 0.023 & 0.011 & 0.547 & 0.528 \\
\hline \multirow[t]{2}{*}{ cyp3a } & $r$ coeff & & 1.00 & 0.6734 & 0.0502 & -0.0279 & -0.0141 & 0.0959 & -0.1910 \\
\hline & $p$ & & & 0.000 & 0.829 & 0.892 & 0.946 & 0.641 & 0.350 \\
\hline \multirow[t]{2}{*}{$a b c c 2$} & $r$ coeff & & & 1.00 & 0.0532 & 0.0117 & -0.0343 & 0.2477 & -0.3217 \\
\hline & $p$ & & & & 0.819 & 0.954 & 0.865 & 0.213 & 0.102 \\
\hline \multirow[t]{2}{*}{ BFCOD } & $r$ coeff & & & & 1.00 & 0.8652 & 0.8650 & -0.2586 & 0.4262 \\
\hline & $p$ & & & & & 0.000 & 0.000 & 0.258 & 0.054 \\
\hline \multirow[t]{2}{*}{ EROD } & $r$ coeff & & & & & 1.00 & 0.8170 & -0.950 & 0.2598 \\
\hline & $p$ & & & & & 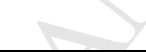 & 0.000 & 0.644 & 0.191 \\
\hline \multirow[t]{2}{*}{ BROD } & $r$ coeff & & & & & & 1.00 & -0.0827 & 0.2915 \\
\hline & $p$ & & & & & & & 0.688 & 0.140 \\
\hline \multirow[t]{2}{*}{ GST } & $r$ coeff & & & & & & & 1.00 & 0.1829 \\
\hline & $p$ & & & & & & & & 0.371 \\
\hline UDPGT & $r$ coeff & & & & & & & & 1.00 \\
\hline
\end{tabular}

$\mathrm{r}=$ Pearson correlation coefficient

$\mathrm{p}=$ significance level $(\mathrm{p}<0.05$ is considered significant $)$ 